\title{
Comparison of vocabularies which has a word beginning with "กิน" (kin/eat) in Thai and “吃” (chī/eat) in Chinese which has implications about sexual behavior
}

\author{
Kritsadee Songkhai \\ College of Chinese Language and Literature \\ Wuhan University
}

\begin{abstract}
There are a lot of words that begin with the word "Eat," both in Thai and Chinese. And, many words have a hidden meaning, for example, The Thai word "กินแห้ว (Eating water chestnut)," can also imply disappointment from your hope not being realized. Another example: Words in Chinese, 吃醋 (chīcù), where the word 吃 (chī), means “eating” and the phrase 醋 (cù), which means "vinegar" and combiningthis two means "eating vinegar." But, this combination implies "jealousy." Therefore, words that have implicit meanings may confuse Thai students and Chinese students. Thus, more profound research can bring understanding to the benefit and efficiency of Thai and Chinese language students.

As a result, we decided to do further research on this topic.Vocabularies which have a word beginning with "Eat" in Thai or Chinese languages and which have implications about "Sexual behavior." Starting with collecting words that begin with the word, "Eat" from the Thai-Thai dictionary and Chinese-Chinese dictionary. In the Thai dictionary, 122 words with the word "Eat," 3 of them have implications about sexual behavior. And, in Chinese dictionaries, 72 words begin with the word “吃” (chī กิน), where the only phrase has implications about sexual behavior: “吃豆腐( chīdoufü)."

Hence, we decided to use the combination of these four words as the initial scope of the study. The research found that "Eat," in Thai may imply having sex. But, there is no Thai dictionary that refers to the meaning "Eat" to having sex. This may confuse those who study Thai as a second language. In Chinese, most of the words beginning with, “吃” (eat) does not mean “having sex." There is only 吃豆腐 (chīdoufü), which means to take liberties, e.g., touching inappropriately, which differentiates the word "Eat" in Thai and Chinese languages.
\end{abstract}

Keywords: eating, sexual behavior, Thai, Chinese

\section{Introduction}

Currently, in Thailand, many business investors come from many countries seeking join investment. Therefore, communication is consideredas an essential part of succeeding in business. One of those investors come from China, and many Chinese businesspeople invest in Thailand. And, it follows that connection between the Thai and Chinese is crucial, which Chinese language in Thailand as important as English.

Having an extensive vocabulary is considered the basis of language. So, choosing the correct vocabulary as being appropriate to the context and environment is essential. Therefore, in this article, we will mention some word, which has inherent meaning. Some vocabulary may confuse students of Chinese language and Thai language as learning as a second language and result in word-misuse. This case is oftenbecause the student does not know the vocabulary's hidden meaning due to it not being explicitly parsed in the dictionary. This oversight can cause errors in effective communication. We picked the topic of "Comparison of Vocabularies," using a word beginning with "Eat" in ThaiChinese, which has implications about "Sexual behavior."

\section{Purposes of the study}

To researchthe Thai Language and Chinese Language vocabularies beginning with "Eat," and findingthe hidden meaning related to "Sexual behavior."

\section{Definition}

The meaning of the word "Eat," according to the Royal Institute Dictionary.

1. Chewing as in eating betel nut; chewing and swallowing such as eating rice; drinking such as drinking water; through the throat down to the stomach

2. Means to waste, such as spending money, wasting time, cause waste, e.g., car burning excess oil; a type of light bulb that consumes a lot of energy. 
3. Accepting such as taking bribes, earning money in bad-faith, such as eat hoeing-eat shovel (to make money dishonestly (Thai idiom); Win through gambling.

4. Verbs "Win," at gambling.

The meaning of the word, “吃,”according to the Modern Chinese Dictionary (2012)

1.(动)把食物等放到嘴里经过咀嚼下去（包括吸、喝）：吃饭、吃奶、吃药。

(verb) Put food in the mouth; chew and eat it (including breathing and drinking): having meals, drinking milk, and taking medicine.

2.(动)依靠某种事物来生活: 吃劳保、吃老本、靠山吃山、靠水吃水。

(verb) Live by something: live on labor security funds, live off one's past gains, those living on a mountain live off the hill, Draw water by water.

3.(动)吸 (液体) : 这种纸不吃墨。

(verb) Absorption (liquid): This kind of paper does not absorb ink.

4.(动)消灭: (多用于军事、祺戏)。

(verb) Elimination: (Mostly used in military and operas).

5.(动)承受: 禁受: 吃得消、吃不住。

(verb) Bear: endure: feel up to doing something but, couldn't stand such a thing.

6.(动)受: 挨: 吃惊、吃亏、吃批评。

(verb) Suffer: Surprise, Losses, Eating criticism.

7. 耗费: 吃劲、吃力。

Cost: Be a strain; be strenuous.

8. (介)被（多用于早起白话）。

(Proposition)often used for early vernacular.

\section{Benefits fromthe research}

1. For those who study Thai and Chinese as a second language to understand the meaning and choose to use the word"Eat," in the context of "Sexual behavior."

2. To be a part of the development in the teaching and learning Thai and Chinese vocabulary.

3. The research hypothesis: There are hidden similarities and differences in both Thai and Chinese; they start with"Eat" in the context of "Sexual behavior."

\section{Research method}

The words that contain the word"Eat" in New Edition Word, Volume 1, (2007), Royal Institute Dictionary (New World Dictionary), parse a total of nine words. Of these nine words, two are implied sexual harassment. These two words are: "Eat egg yolks" and "Eat black beans."

The words that contain the word "Eat" in New Edition Word, Volume 2, (2009), Royal Institute Dictionary, parse a total of five words. There are no words that have implications for sexual harassment, but there is one word that implies having sex, that is literally, "Eating child (Consuming the younger partner)."

The words that contain the word "Eat" in New Edition Word, Volume 3, (2011), Royal Institute Dictionary, parse a total of nine words. There are no words that have implications for sexual harassment.

The Royal Institute Dictionary, (2011) parse a total of 99 words. The word "Eat" has no reference to sexual harassment. There is a total of 72 words in the Chinese dictionary,(2018), and these include the word "吃”, which means, "Eating." In this case, one word has implications as sexual harassment: “吃豆腐 (chīdòufú)” (Inappropriate touching/ molest)

Therefore, we chose to compare the Thai and Chinese words with the word "Eat." From a total of 122 Thai words, found two words that imply sexual harassment, they are:"Eat egg yolk" and "Eat black beans" and the other one word means having sex and it is"Eating children."Also found 72 Chinese words that contain the word "Eat" and only one word impliedsexual harassment, and it is“吃豆腐 (chīdòufú)" Which means Inappropriate touching/ molest.

Therefore, in theoretically analyzing this article, we researched three words: 1.กินไข่แดง (gin kàidaeng/Eat egg yolks) 2.กินถั่วดำ (gin tùa-dam /Eat black beans) 3.กินเด็ก (gin dèk/Eat child) 4. 吃豆腐 (chīdòufǔ/Inappropriate touching). 


\section{Theory}

We chose the method of Lakoff\& Johnson (1980) "Conceptual Metaphors" for this case study. Lakoff\&Johnson explained a new concept in "Metaphors in We Live By" and offered a perspective on "Conceptual Metaphor Theory" states that metaphors appear everywhere in daily human language, that affects thinking processes and human behavior. "Language" is the crucial evidence that reflects the "Human conceptual system." The processing system iscalled "mapping," which pairs two conceptual circles or bands between the Original meaning to the Objective meaning or purpose. When people find new things, they often paired experience as in the latest between the old using existing knowledge as a mean asto understand and apply new meaning to the language according to the guidelines, "Parish linguistics" (Lakoff\&Johnson,1980).

\section{Content}

The word "Eat" in Thai dictionary by The Graduate version (2011), It gives four meanings, while the word, "吃" (chī eat) in the Chinese Contemporary Chinese Dictionary (2018) gives eight meanings. See table:

\begin{tabular}{|c|c|c|}
\hline \multicolumn{3}{|c|}{ Vocabulary comparison table "Eat" in Thai and “吃" in Chinese } \\
\hline & $\begin{array}{l}\text { Meaning "Eat" } \\
\text { In the Thai-ThaiRoyal } \\
\text { Institute Dictionary (2011) }\end{array}$ & $\begin{array}{l}\text { Meaning “吃”(chī) in Chinese Contemporary Chinese Dictionary } \\
\text { (2018). }\end{array}$ \\
\hline Meaning 1 & $\begin{array}{l}\text { 1.Chewing as in chewing } \\
\text { betel nut; chewing and } \\
\text { swallowing such as eating } \\
\text { rice; drinking such as } \\
\text { drinking water; through } \\
\text { the throat down to the } \\
\text { stomach. }\end{array}$ & $\begin{array}{l}\text { 1.(动)把食物等放到嘴里经过咀嚼下去（包括吸、喝）：吃 } \\
\text { 饭、吃奶、吃药 } \\
\text { (verb) Put food in the mouth, chew and eat it (including } \\
\text { breathing and drinking): having meals, drinking milk and taking } \\
\text { medicine. }\end{array}$ \\
\hline Meaning 2 & $\begin{array}{l}\text { 2.It means to waste, such } \\
\text { as spending money, } \\
\text { wasting time, cause waste, } \\
\text { e.g., car burning excess } \\
\text { oil; a type of light bulb } \\
\text { that consumes a lot of } \\
\text { energy }\end{array}$ & $\begin{array}{l}\text { 2. (动) 依靠某种事物来生活: 吃劳保、吃老本、靠山吃山 } \\
\text { 靠水池水 } \\
\text { (verb) Live by something: live on labor security funds, live off } \\
\text { one's past gains, those living on a mountain live off the hill, } \\
\text { Draw water by water. }\end{array}$ \\
\hline Meaning 3 & $\begin{array}{l}\text { 3.Accepting such as taking } \\
\text { bribes, earning money in } \\
\text { bad-faith, such as eat } \\
\text { hoeing-eat shovel (to } \\
\text { make money dishonestly } \\
\text { (Thai idiom); Win through } \\
\text { gambling. }\end{array}$ & $\begin{array}{l}\text { 3.(动)吸 (液体)：这种纸不吃墨 } \\
\text { (verb) Absorption (liquid): This kind of paper does not absorb } \\
\text { ink. }\end{array}$ \\
\hline Meaning 4 & $\begin{array}{l}\text { 4.Verbs "Win," at } \\
\text { gambling. }\end{array}$ & $\begin{array}{l}\text { 4.(动)消灭: (多用于军事、祺戏) } \\
\text { (verb) Elimination: (Mostly used in military and operas). }\end{array}$ \\
\hline Meaning 5 & & $\begin{array}{l}\text { 5.(动)承受: 禁受: 吃得消、吃不住 } \\
\text { (verb) Bear: endure : feel up to doing something but, couldn't } \\
\text { stand such a thing. }\end{array}$ \\
\hline Meaning 6 & & $\begin{array}{l}\text { 6.(动)受: 挨: 吃惊、吃亏、吃批评 } \\
\text { (verb) Suffer: Surprise, Losses, Eating criticism. }\end{array}$ \\
\hline Meaning 7 & & $\begin{array}{l}\text { 7. 耗费: 吃劲、吃力 } \\
\text { Cost: Be a strain; be strenuous. }\end{array}$ \\
\hline Meaning 8 & & $\begin{array}{l}\text { 8. (介) 被（多用于早起白话） } \\
\text { (Proposition) often used for early vernacular. }\end{array}$ \\
\hline
\end{tabular}


Therefore, dictionaries show that words beginning with"Eat," in Thai and Chinese languages do not mean sexual behavior or sexuality nor sexual harassment.

However, analyzing the data collected, there are three Thai words, relating to sexual behavior:"Eating egg yolks, eating black beans and eating children.”There is only one Chinese word, “吃豆腐” that relates to "Sexual behavior."

\section{Word Analysis}

\section{Eat egg yolks (gin kàidaeng/ กินไข่แดง)}

Eating egg yolks means "Taking a woman's virginity," e.g., sentences like, "Girls, do not believe what the young boy is saying. He will lure you into eating your egg yolk". (Quoted from the book) this context means "Having sex" when viewed according to the image of the yolk is being eaten.

\section{Egg yolk implies the woman's virginity, whereas the yolk is being eaten."Having sex" for the first time} as is breaking the egg yolk.

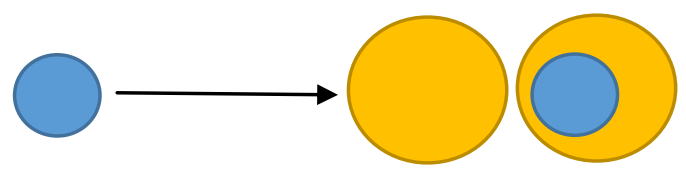

Yellow refers to the word"Eat" and implies negatively having sex as it means the taking/destroying the woman's virginity Blue refers to "egg yolk" and indicates a virgin woman.

\section{Eat black beans (gin tùa-dam/ กินถั่วดำ)}

Eat black beans, refers "Male homosexuality" e.g., "Look at this muscular man. Everyone knows he eats black bean types (Eating black beans derives from the nickname of a man arrested by police in 1935 for sexual misconduct with many boys and forcing those boys to prostitute themselves.)

This word derived from another word which does not have a meaning related to the phrase "Eat."

\section{Eat child (gin dèk/ กินเด็ก)}

Eating a child means:

1. (verbs) has a much younger partner (Generally, used with women or shemale).

2. (verbs) have sexual relations with a younger partner.

\section{A child (younger partner) was eaten}

\section{Eat implies having sex.}

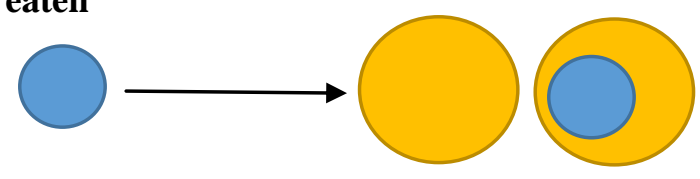

Yellow represents the word "Eat."

The dictionary gives two meaning: The first meaning is having a lot of younger partner. We will focus only on the second meaning, "eating" as in having sex. Blue refers to "child" as in a younger person.

We can see that the word "Eat" in Thai means"Sexual harassment" and "Eating child" refers to sexual intercourse with a younger partner. Interestingly, there is one slang word that reflects the word "Eat" in the Thai language relating to sexual behavior. Where promiscuity means, "Eat liver." From the name of a song in 2011 and which won the 8th Greater Award, a favorite country music award,

In older dictionaries, the meaning of "Eat" has no meaning to related to sexual behavior.However, it has appeared in the new dictionary. Due to the modern society era, that is more confident and curious in daring to talk and communicate about this kind of words. But Thai society is still an indirect society in terms of sexuality. Therefore, Thai use other words to imply sexual behavior for reasons of comfort to talk about the subject with less embarrassment.

In the Chinese language, the word“吃” does not relate to sex. There is an only word, “吃豆腐(chīdòufú)” and that refers to inappropriate touching (sexually), (Li. Z G,2017). “吃豆腐(chīdòufǔ)” can be translated: “吃(chī)”means eat, and “豆腐(dòufŭ)," means bean curd and when combining the both is"Eat a bean curd." Initially, this word had derived from the ancient Chinese's era, when someone died the Chinese used bean curd to welcome guests. Sometimes there might be some people who came to eat but, not to express sympathy or support. The meaning of “豆腐” itself means "Taking advantage of the others." 
In a later age, the word's meaning has grown to suggest or imply Sexual harassmentthe purpose derived from a story about there was a tofu shop opened in Chang'an street Anhui province. The seller was initially beautiful and eat the bean curd as beauty function as her regular food. Bean curd could make skin fine and tender. She was called "Beancurd queen," to attract customers, "Bean-curd queen"will inevitably have a show of style, leading the surrounding men to "eat the bean curd." As a result, the wives are not satisfied and jealous, so the wives often reprimanded her husband with "Do you go to eat bean curd today?" Later, "eat bean curd" became synonymous with men's who frivolous women.

As we can see the word "Eat" in both Thai and Chinese language has sexual behavior meaning, but in Chinese,

“豆腐(dòufü)" is meant“Inappropriatesexual touching or molest."

This word has a history that is not about eating in either language. However, in the Thai language the words: Eat egg yolk, eat black beans, eat child, eat liver, all have a meaning that represents sexual behavior or having sex. So, it is the deduction that the word "Eat" infers having sexual intercourse. However, in Thai dictionaries, no reference says"Eat" as sexual behavior. Therefore, a person learning Thai has no point of reference to understand and hence, may cause misuse of the word in Thai.

\section{Conclusion}

The word "Eat," in each of the Thai and Chinese languages have more than one meaning. Therefore, choosing the correct vocabulary is fundamentally essential to communication in many languages. Thai dictionaries do not specify the meaning of the word"Eat,"concerning as sex. Therefore, it would be helpful for the dictionaries to include the definition of "Eat" concerning sex. A conclusion is that Chinese dictionaryis more up to date than Thai dictionary as we can be seen by the publishing date, while Thai Royal Institute Dictionary published in 2011, and the Chinese Contemporary Chinese Dictionaryin 2018.

This grave oversight of the importance of the Thai language keeping pace with change. Which means students, economists, civilization, and Thai culture have no reference point for people needing to communicate in the Thai language.

\section{References}

\section{Thai}

TianchaiIamworawet. (2002). Chinese-Thai dictionary (New version). Bangkok: Ruamsart.

Royal Society of Thailand. (1999). Royal Institute Dictionary. Bangkok: Nanmeebooks Publishing.

Royal Society of Thailand. (2007). Royal Institute of New Words Dictionary 1. Bangkok: Tana Press.

Royal Society of Thailand. (2009). Royal Institute of New Words Dictionary 2. Bangkok: Nanmeebooks Union UltraViolet Co., Ltd

Royal Society of Thailand. (2011). Royal Institute of New Words Dictionary 3. Bangkok: Nanmeebooks. Union UltraViolet Co., Ltd.

\section{Chinese}

Li ZhiGuo. (2017). "How eating tofu” has evolved into taking advantage. Culture and History Vision. Hunan: Culture and History Vision Publishing.

Chen Bi Yao. (2014). Why flirting is "eating tofu." Yao. Shanghai: Shanghai Culture Publishing.

CengJia. (2013). The Metaphor of "Eating" in Chinese. Southwest University. Chongqing: Journal of Southwest University.

Modern Chinese Dictionary.(2012). Beijing :The Commercial Press.

\section{English}

Lakoff, G.; \& Johnson, M. (1980). A metaphor we live by. Chicago: University of Chicago Press. 